\title{
JMS
}

P-ISSN: 2722-9270 ejournal.uksw.edu/jms

\section{Pelatihan Visualisasi Molekul Kimia dengan Software Chemsketch untuk Siswa Tingkat Sekolah Menengah Atas}

\author{
Esti Mulatsari* \\ Esti Mumpuni \\ Liliek Nurhidayati \\ Agus Purwanggana \\ Diah Kartika Pratami \\ Fakultas Farmasi, Universitas Pancasila
}

\section{A R T I C L E I N F O}

Article history:

Received 22-09-2021

Revised 26-09-2021

Accepted 15-11-2021

Key words:

Training, ChemSketch, Chemical Structure, Senior High School

\begin{abstract}
A B S T R A C T
Senior High School (SMA) has a very broad scientific scope, one of which is chemistry. In chemistry, it presents the processes, chemical notations, types, and arrangements of matter. Chemical processes can be written in a concise form, such as a reaction equation, without eliminating the microscopic and macroscopic aspects that occur in the chemical process. This equation for the reaction is a symbolic aspect of chemistry. All the substances involved in the equation of the reaction are also symbolic aspects of chemistry. In other words, chemical formulas, such as atomic symbols, element symbols, compound symbols or formulas, all of these are symbolic aspects of chemistry. This symbolic aspect is of great importance in chemistry. Training on the use of ChemSketch software is very important for high school students, especially science majors, as an enrichment for chemistry subjects and improves skills in presenting chemical data in order to improve the quality of graduates. ChemSketch software provides process symbols, chemical notations, types, arrangement of materials, and several image representations of various laboratory tools, which are quite easy to use. Training on the use of ChemSketch for SMA N 13 Depok students has been enthusiastically carried out online, the material is relevant to chemistry subject matter, easy to accept and the delivery of the material is quite interesting.
\end{abstract}

\begin{abstract}
A B S T R A K
Sekolah Menengah Tingkat Atas (SMA) memiliki ruang lingkup keilmuan yang sangat luas salah satunya ialah ilmu kimia. Di dalam ilmu kimia menyajikan proses, notasi-notasi kimia, jenis, dan susunan materi. Proses-proses kimia dapat dituliskan dalam bentuk yang ringkas, seperti persamaan reaksi, dengan tidak menghilangkan aspek mikroskopis dan makroskopis yang terjadi pada proses kimia tersebut. Persamaan reaksi ini merupakan aspek simbolis dalam kimia. Semua zat yang terlibat dalam persamaan
\end{abstract}


reaksi juga merupakan aspek simbolik dari kimia. Dengan kata lain, rumus-rumus kimia, seperti lambang atom, lambang unsur, lambang atau rumus senyawa, semuanya ini merupakan aspek simbolis dari kimia. Aspek simbolis ini merupakan hal penting dalam kimia. Pelatihan penggunaan software ChemSketch menjadi hal yang sangat penting dilakukan untuk siswa SMA khususnya jurusan IPA sebagai pengayaan pada mata pelajaran kimia dan meningkatkan skill dalam penyajian data kimia guna meningkatkan kualitas lulusan. Software ChemSketch menyajikan simbol-simbol proses, notasi-notasi kimia, susunan materi, dan beberapa penyajian gambar berbagai alat laboratorium, yang cukup mudah untuk digunakan. Pelatihan penggunaan ChemSketch untuk siswa SMA N 13 Depok telah dilaksanakan secara online dengan penuh antusias, materi relevan dengan materi pelajaran kimia, penyampaian materi mudah diterima dan cukup menarik.

\section{PENDAHULUAN}

Dalam penyelenggaraan pendidikan tingkat Sekolah Menengah Atas (SMA) akan mencakup bidang keilmuan yang sangat luas, salah satunya ialah ilmu kimia (Kemdikbud, 2017). Ilmu kimia sangat dibutuhkan sebagai ilmu dasar bagi siswa khususnya jurusan IPA. Ilmu kimia mempelajari tentang struktur, susunan, sifat, dan perubahan materi, serta energi yang menyertai perubahan tersebut (Afnidar dkk, 2014). Pembahasan tentang struktur materi mencakup struktur partikel yang menyusun materi dan bagaimana partikel-partikel sangat kecil tersebut bergabung membentuk materi dengan ukuran yang lebih besar sehingga nanti bisa diamati. Sifat materi dideskripsikan sebagai sifat kimia yang berhubungan dengan jenis partikel materi. Hal-hal tersebut sangat penting dipelajari sebagai landasan sintesis obat, pengetahuan mekanisme reaksi obat, dan penjelasan ilmiah terkait manfaat obat (Handayany, 2020).

Kimia menyajikan proses, notasi-notasi kimia, jenis, dan susunan materi. Prosesproses kimia dapat dituliskan dalam bentuk yang ringkas, seperti persamaan reaksi. Persamaan reaksi ini merupakan aspek simbolis dalam kimia. Semua zat yang terlibat dalam persamaan reaksi juga merupakan aspek simbolik dari kimia (Putri, 2016). Dengan kata lain, rumus-rumus kimia, seperti lambang atom, lambang unsur, lambang atau rumus senyawa, semuanya ini merupakan aspek simbolis dari kimia yang sangat penting untuk diketahui.

Aspek-aspek simbolis ini, membuat mata pelajaran kimia terkesan menjadi mata pelajaran yang rumit bagi sebagian besar siswa. Karena selain banyaknya simbol materi yang dipelajari dalam kimia hampir semua bersifat abstrak. Hal ini menyebabkan siswa kesulitan dalam memahami materi pembelajaran. Beberapa faktor yang teridentifikasi sebagai penyebab kesulitan di antaranya karena benak seseorang perlu mengimajinasikan antara struktur 3D suatu molekul dengan gambar yang dicetak dalam bentuk 2D (Abraham, Varghese \& Tang. 2010).

Salah satu media pembelajaran dengan tekonologi modern yang dapat menarik perhatian siswa adalah menggunakan komputer. Belajar secara konvensional, membuat simbol-simbol kimia pada selembar kertas, dapat membuat siswa jenuh dan sulit untuk memahami materi pembelajaran. Berkembangnya teknologi yang semakin modern, menuntut pembaruan dalam pembelajaran. Guru dan siswa harus mampu 
menggunakan alat-alat pendukung agar proses pembelajaran dapat berjalan dengan lancar dan siswa lebih mampu memahami materi pembelajaran dan Guru lebih mudah dalam menyampaikan materi (Arsyad. 2015). Komputer merupakan media pembelajaran yang terdiri dari komponen warna, musik, dan animasi grafis yang dapat digunakan sebagai media. Dengan kata lain media adalah komponen sumber belajar yang mengandung materi instruksional di lingkungan siswa yang dapat merangsang siswa untuk belajar (Sadiman. 2014).

SMA Negeri 13 Depok merupakan SMA yang memiliki kegiatan belajar mengajar meliputi penyajian teori di kelas dan praktek di laboratorium. Dalam bidang ilmu kimia belum pernah dikenalkan kepada para siswa mengenai media penyajian notasi-notasi dan simbol-simbol kimia berbasis software/komputer sehingga produk penyajian notasi-notasi dan simbol-simbol kimia tidak konsisten dan kurang memenuhi kaidah keilmuan karena disajikan secara manual (menggambar dengan pena) sedangkan proses menggambar notasi-notasi dan simbol-simbol kimia dengan program Microsoft Word yang sudah familiar bagi sebagian besar siswa akan memberi hasil yang kurang sesuai dengan kaidah penulisan simbol. Beberapa rumus kimia dalam pembelajaran kimia SMA salah satunya adalah senyawa-senyawa hidrokarbon. Di SMA Negeri 13 Depok struktur disajikan dalam bentuk 2D, sehingga sulit untuk menjelaskan posisi masing-masing atom terhadap atom yang lain, sedangkan untuk menggambar dalam bentuk 3D secara manual atau menggunakan Microsoft word cukup merepotkan.

Permasalahan tersebut terjadi dikarenakan aspek inovasi media pembelajaran di sekolah yang masih terbatas, sumber daya manusia (guru-guru) yang jumlahnya masih terbatas dan belum menguasai media berbasis software dan siswa-siswi yang cenderung pasif dengan perkembangan teknologi. Siswa lebih termotivasi untuk mempelajari materi bentuk molekul (Asyhar, 2012). Pelatihan penggunaan software ChemSketch kepada para SMA Negeri 13 Depok menjadi hal yang sangat penting untuk meningkatkan skill para siswa. Software ChemSketch merupakan software yang mudah digunakan. Dalam ChemSketch terdapat piranti yang dapat digunakan untuk membuat nama dan struktur senyawa, memberi informasi terkait rumus molekul, berat molekul dan sifat fisika kimia nya, membuat struktur stereokimia, membuat persamaan atau mekanisme reaksi dan menggambar berbagai alat - alat laboratorium kimia, Kelebihan lain dari software ini adalah bisa diakses secara gratis (freeware) [acdlabs.com, 2020]. Dengan pelatihan ini diharapkan para siswa memiliki skill dalam hal penyajian data, simbol ataupun notasi - notasi kimia dengan cara yang menyenangkan dan menghasilkan output symbol yang rapi dan sesuai kaidah. Penggunaan software Chemsketch dapat memperjelas pemahaman konsep abstrak dalam mata pelajaran kimia sehingga dapat menjadi lebih konkrit, mudah ditangkap oleh otak siswa dan menyenangkan untuk diikuti penjelasannya.

\section{METODE PELAKSANAAN}

Metode pelaksanaan kegiatan pengabdian kepada masyarakat di SMA Negeri 13 Depok diuraikan dengan diagram pada Gambar 1. 


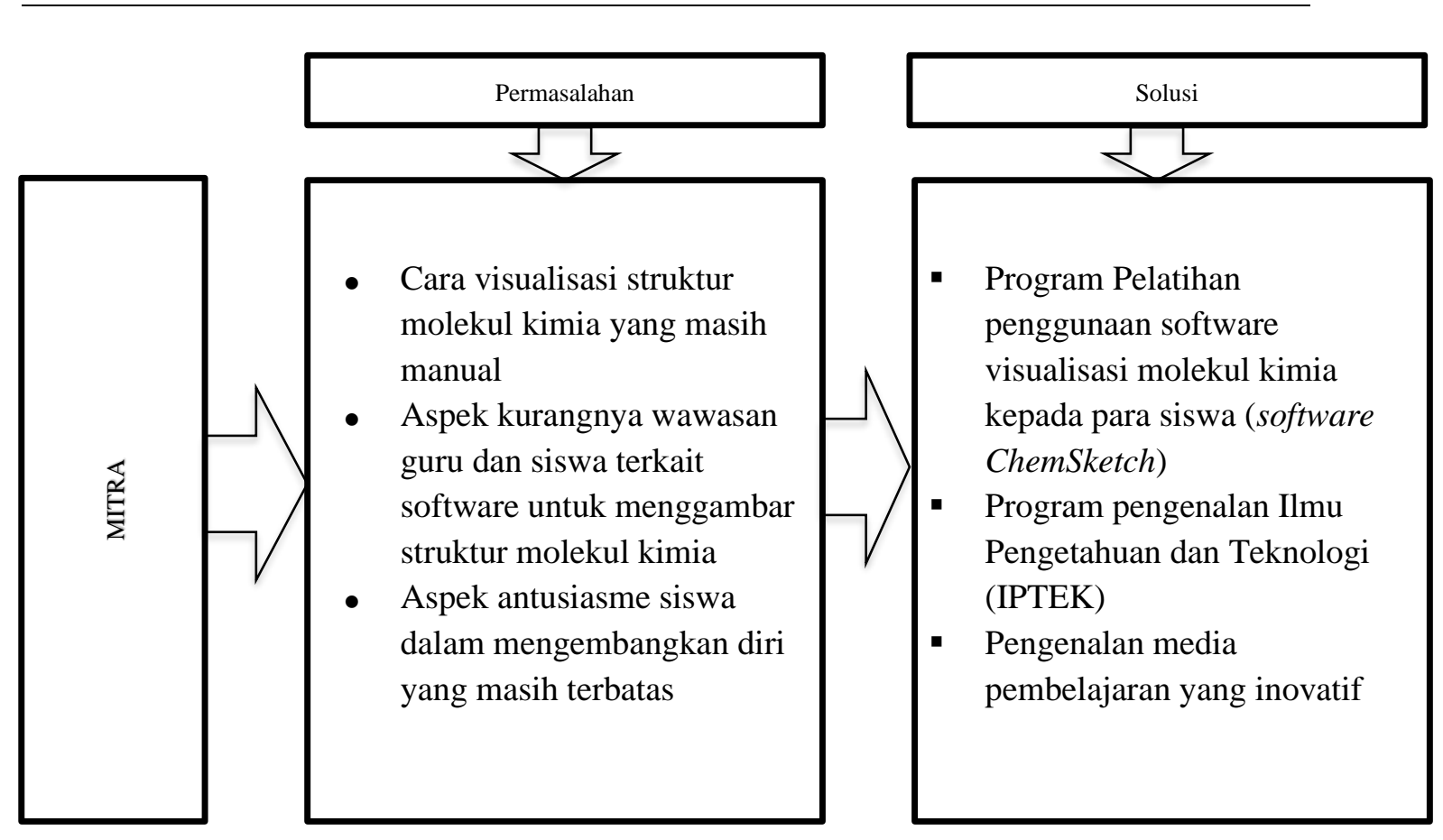

Gambar 1. Diagram Identifikasi Masalah

\subsection{Tahap Pelaksanaan Pengabdian}

Metode pelaksanaan kegiatan program pengabdian masyarakat (PKM) adalah berupa pelatihan secara daring dengan sasaran utama para siswa. Kegiatan pelatihan visualisasi molekul dengan software ChemSketch sebagai materi pengayaan untuk siswa SMA Negeri 13 Depok. Langkah-langkah pelaksanaan kegiatan program pengabdian kepada masyarakat dibagi dalam tiga tahapan yaitu 1) tahap persiapan/sosialisasi, 2) tahap pelaksanaan 3) tahap pelaporan dengan rin adalah sebagai berikut :

\subsubsection{Tahap Persiapan}

\section{a. Berkoordinasi dengan pihak sekolah}

Koordinasi dilakukan oleh tim pelaksana PKM dengan pihak sekolah khususnya Wakil Kepala Sekolah Bidang Kesiswaan SMA Negeri 13 Depok berkaitan dengan kegiatan pelatihan, terutama mengenai teknis dan jadwal pelaksaan. Pihak sekolah diharapkan dapat membentuk tim pelaksana dalam menyiapkan sarana dan prasarana penunjang kegiatan pelatihan. Pihak sekolah mengarahkan para siswa jurusan IPA untuk megikuti kegiatan pelatihan.

\section{b. Penyiapan Materi Pelatihan dan Materi Pre Test}

Sebelum pelaksanaan kegiatan pelatihan tentang penggunaan ChemSketch, tim pelaksana PKM menyusun buku panduan pelatihan, menentukan batasan materi yang akan disampaikan, membuat slide presentasi, menyiapkan soal-soal Latihan dan lembar kuisioner untuk peserta (siswa) dan guru. Buku panduan ini akan digunakan para siswa sebagai panduan dalam pelaksanaan pelatihan. Materi buku panduan ini dikembangkan dari petunjuk ChemSketch (acdlab, 2020). Materi pelatihan dibuat dari struktur senyawa kimia yang paling sederhana sampai struktur kimia yang kompleks 
dan persamaan reaksi. Dari struktur senyawa kimia dua dimensi, materi dikembangkan lebih lanjut ke struktur senyawa kimia tiga dimensi, pemberian nama dari struktur senyawa kimia, penentuan sifat-sifat senyawa kimia, orbital atom, diagram, dan alat praktikum kimia.

\subsubsection{Tahap Pelaksanaan}

\section{a. Pelaksanaan pelatihan ChemSketch}

Pelaksanaan pelatihan diawali dengan materi pengenalan berbagai software yang dapat dimanfaatkan untuk visualisasi molekul kimia dan pendukung pembelajaran kimia, dilanjutkan dengan praktik penggunaan ChemSketch didasarkan atas buku panduan pelatihan yang telah disiapkan. Pada kegiatan pelatihan ini setiap siswa memegang satu set laptop. Peserta berlatih membuat struktur senyawa kimia dari struktur sederhana ke struktur kompleks dan seterusnya sesuai dengan urutan dalam materi pelatihan.

\section{b. Pembuatan media presentasi}

Diakhir kegiatan pelatihan seluruh peserta akan dilatih untuk mengintegrasikan hasil struktur yang telah mereka kerjakan ke dalam media ppresentasi kimia. Media presentasi yang dibuat oleh peserta berbasis powerpoint. Peserta diberi kebebasan memilih software powerpoint tergantung dari penguasaan, kesukaan, atau tingkat kemudahan yang dirasakan oleh peserta. Gambar berupa struktur senyawa kimia yang telah dibuat dengan Chemdraw disalin (di-copy) dan kemudian di tempel (di-paste) pada slide powerpoint. Kegiatan ini dilakukan untuk meningkatkan ketrampilan siswa dalam proses penyajian materi presentasi yang memuat materi - materi notasi atau simbol - simbol struktur kimia dan persamaan reaksi, selain itu hasil integrasi ini akan dijadikan acuan/tolok ukur kepahaman siswa dalam menerima materi pelatihan.

\section{c. Evaluasi}

Proses evaluasi dilakukan di akhir kegiatan untuk mengetahui tingkat keberhasilan pelatihan. Beberapa aspek yang dievaluasi ditampilkan pada Tabel 1.

Tabel 1. Aspek Evaluasi Kegiatan Pengabdian

\begin{tabular}{ll}
\hline \multicolumn{1}{c}{ Aspek yang dievaluasi } & \multicolumn{1}{c}{ Indikator Capaian } \\
\hline $\begin{array}{l}\text { Kualitas produk struktur senyawa kimia yang } \\
\text { dihasilkan para siswa saat pelatihan }\end{array}$ & $\begin{array}{l}\text { Nilai kualitas produk struktur senyawa kimia } \\
\text { yang dihasilkan para siswa saat pelatihan dalam } \\
\text { rentang nilai } 70-90\end{array}$ \\
\hline $\begin{array}{l}\text { Pendapat para siswa terhadap pelaksanaan } \\
\text { pelatihan penggunaan software ChemSketch }\end{array}$ & $\begin{array}{l}\text { Pendapat siswa terhadap pelatihan penggunaan } \\
\text { software Chemdraw tergolong kategori setuju }\end{array}$ \\
\hline $\begin{array}{l}\text { Pendapat guru sekolah terhadap pelaksanaan } \\
\text { pelatihan penggunaan software ChemSketch }\end{array}$ & $\begin{array}{l}\text { Pendapat guru terhadap pelatihan penggunaan } \\
\text { software Chemdraw tergolong kategori setuju }\end{array}$ \\
\hline
\end{tabular}




\section{HASIL DAN PEMBAHASAN}

\subsection{Tahap Persiapan Kegiatan}

\subsubsection{Koordinasi Tim Pelaksana PKM}

Dalam rangka memperlancar proses persiapan dan pelaksanaan kegiatan pelatihan, tim pelaksana PKM melakukan rapat koordinasi untuk membuat rencanarencana kegiatan, sarana prasarana yang dibutuhkan dan pembagian job desk untuk kegiatan pelatihan. Rapat koordinasi dilakukan melalui daring dan diikuti seluruh tim pelaksana, sedangkan untuk mahasiswa dan tenaga pendidik yang terlibat dilakukan komunikasi melalui WAG yang telah dibuat sebagai sarana komunikasi tim.

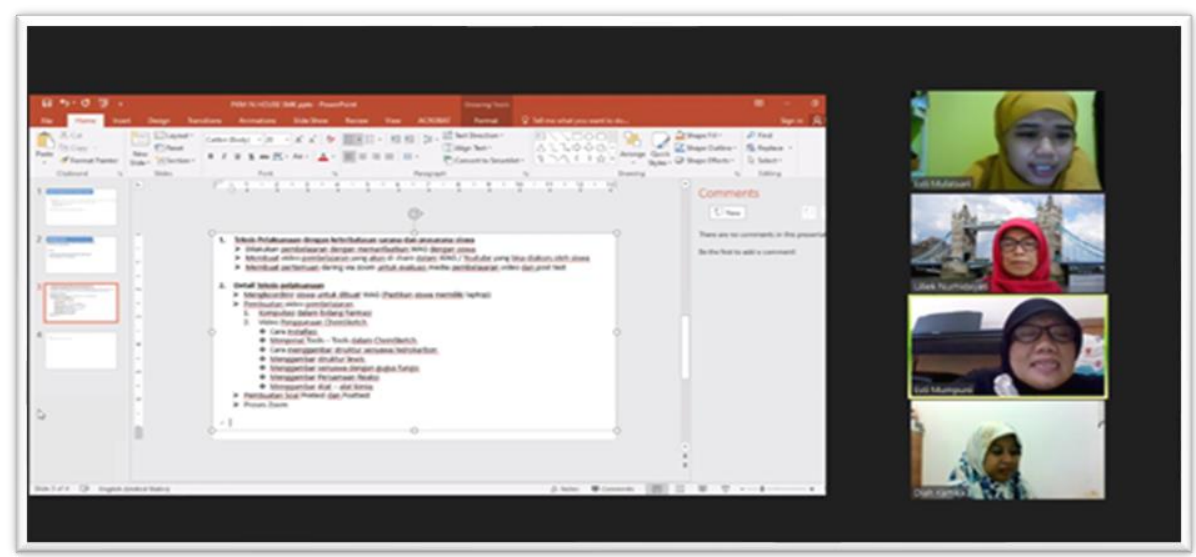

Gambar 2. Dokumentasi Rapat Koordinasi Tim PKM

\subsubsection{Berkoordinasi dengan pihak sekolah}

Koordinasi dilakukan oleh tim pelaksana PKM dengan pihak sekolah khususnya Wakil Kepala Sekolah Bidang Kesiswaan SMA N 13 Depok berkaitan dengan kegiatan pelatihan, terutama mengenai jadwal pelaksanaan dan metode pelaksanaan. Pihak sekolah membantu tim pelaksana dalam hal mengkoordinir para siswa. Tim pelaksana PKM menyiapkan segala sarana prasarana seperti flyer kegiatan, link zoom meeting, run down acara dan kelengkapan-kelengkapan pelatihan. Koordinasi dengan pihak sekolah dilakukan melalui komunikasi via Whattapp.

\subsubsection{Penyiapan Kelengkapan Pelatihan}

Sebelum pelaksanaan kegiatan pelatihan tentang penggunaan Chemskecth, tim pelaksana PKM menyusun flyer publikasi, form registrasi, form presensi, buku panduan pelatihan dalam bentuk e-modul, menentukan batasan materi yang akan disampaikan, membuat slide presentasi untuk materi pengenalan komputasi dan manfaatnya di bidang kimia, farmasi dan kesehatan, menyiapkan soal-soal untuk penugasan dan lembar kuisioner untuk peserta (siswa) dan guru. Buku panduan dalam bentuk e-modul digunakan para siswa sebagai panduan dalam pelaksanaan pelatihan/ praktik. Materi pelatihan dibuat dengan cakupan materi struktur senyawa kimia yang paling sederhana sampai struktur kimia yang kompleks dan persamaan reaksi. Dari struktur senyawa kimia dua dimensi, materi dikembangkan lebih lanjut ke struktur 
senyawa kimia tiga dimensi, pemberian nama dari struktur senyawa kimia, menggambarkan struktur lewis, alat - alat praktikum kimia dan membuat media presentasi dari hasil gambar Chemsketch.

\subsection{Tahap Pelaksanaan Kegiatan}

Kegiatan diselenggarakan pada tanggal 15 November 2020 secara daring dengan menggunakan zoom meeting platform. Kegiatan berlangsung dari jam 08.00 s.d 12.00. dengan rundown acara sebagaimana Tabel 2.

Tabel 2. Rundown Kegiatan Pelatihan Online Penggunaan Software ChemSketch

\begin{tabular}{|c|c|}
\hline Waktu & Kegiatan \\
\hline $07.30-08.00$ & Registrasi Peserta/Absensi \\
\hline $08.00-08.05$ & Pembukaan oleh MC \\
\hline $08.05-08.15$ & $\begin{array}{l}\text { Kata Sambutan dari pihak Sekolah } \\
\text { (Kepala Sekolah atau yang mewakili) }\end{array}$ \\
\hline $08.15-08.25$ & Kata Sambutan dari tim PKM \\
\hline $08.25-08.30$ & Foto bersama \\
\hline $08.30-09.00$ & $\begin{array}{l}\text { Pengenalan Komputasi dalam bidang Kimia, Farmasi dan } \\
\text { Kesehatan }\end{array}$ \\
\hline $09.00-09.30$ & Proses Install Software \\
\hline $09.30-10.30$ & $\begin{array}{l}\text { Penyampaian Materi dan Praktik Langsung } \\
\text { - } \quad \text { Mengenal Tools dalam ChemSketch } \\
\text { - } \quad \text { Menggambar struktur senyawa hidrokarbon 2D/3D } \\
\text { - } \quad \text { Menggambar struktur lewis } \\
\text { - } \quad \text { Menggambar senyawa dengan gugus fungsi } \\
\text { - } \text { Menggambar Persamaan Reaksi } \\
\text { - } \quad \text { Menggambar Alat-alat laboratorium kimia } \\
\text { - } \quad \text { Convert structure to name } \\
\text { - } \text { Copy paste struktur dari lembar kerja chemsketch ke word/ } \\
\text { power point }\end{array}$ \\
\hline $10.30-11.00$ & Latihan - Latihan \\
\hline $11.00-11.30$ & Dorprize dan Pengumuman Peserta terbaik \\
\hline $11.30-12.00$ & $\begin{array}{l}\text { Pemberian Ucapan Terima Kasih untuk Pihak Sekolah } \\
\text { Penyampaian Kesan Pesan dari Guru dan Siswa Penutupan }\end{array}$ \\
\hline
\end{tabular}

Pelaksanaan pelatihan diawali dengan registrasi peserta dengan mengisi googleform registrasi, setiap peserta yang telah melakukan registrasi diarahkan untuk join di wag peserta untuk mempermudah komunikasi, memberi informasi serta share materi sebelum dan saat pelaksanaan pelatihan. Pada saat pelaksanaan pelatihan peserta mengisi presensi melalui googleform yang telah disiapkan tim PKM dan bersamaan dengan sesi tersebut diputar video profil FFUP dalam layar zoom meeting. 
Pelatihan dimulai pukul 08.00 dengan diawali sambutan dari WaKa sekolah bidang kesiswaan, Ibu Retno Santy Ariestuti, S.S. Dalam sambutannnya, Ibu Santy menyampaikan apresiasi yang sangat besar terhadap kegiatan pelatihan yang diselenggarakan, sebagai program baru di sekolah dan memperkaya skill siswa dan guru. Pembukaan acara dari tim PKM diwakili Bapak Apt. Drs. Agus Purwanggana.

Materi pengenalan komputasi dan manfaat komputasi di bidang kimia, farmasi dan kesehatan disampaikan oleh Dr. Apt. Esti Mumpuni, M.Si. Dalam materi pengenalan komputasi disebutkan bahwa komputasi merupakan adalah bidang ilmu yang menggunakan computer untuk menganalisis dan memecahkan masalah-masalah ilmu/sains (https://id.wikipedia.org/wiki/Komputasi). Komputasi yang sangat bermanfaat diberbagai bidang, khususnya dalam bidang Kesehatan, Farmasi dan Kimia. Manfaat komputasi dalam bidang kesehatan antara lain untuk mendiagnosa suatu penyakit dan menentukan obat yang cocok, Melihat dan menganalisa organorgan tubuh bagian dalam manusia, memonitoring status pasien, merecord data pribadi pasien dan riwayat penyakit pasien, melakukan penelitian ilmiah yang diperlukan, memasukkan, menyimpan, menggelompokkan dan mengolah data secara cepat dan mudah, mendeteksi DNA seseorang, mengecek dan mengetahui hasil tes darah di laboratorium (Suhendra A., 2015). Dalam bidang Farmasi, komputasi sangat bermanfaat untuk mendukung sistem informasi instalasi farmasi, yaitu sistem untuk mengelola data atau informasi tentang input data barang, transaksi atau distribusi barang-barang kebutuhan di instalasi farmasi sampai dengan pembuatan laporan, sistem informasi apotek, yaitu sistem pengelolaan data yang dihasilkan dari proses manajemen di unit apotik dari input data sampai dengan output data, sebagai Pusat Informasi Obat dan Komunikasi apoteker dan pasien. Selain itu dalam bidang farmasi ilmu komputasi sangat berkembang pesat dengan banyak manfaat antara lain komputasi digunakan untuk mendesain/membuat obat baru dan memprediksi khasiat senyawa-senyawa dalam suatu tanaman berdasarkan struktur molekulnya, dimana pada jenjang perguruan tinggi diajarkan melalui matakuliah kimia farmasi (Muchtaridi, 2018)

Setelah pemaparan materi pengenalan komputasi, masuk ke acara inti yaitu pelatihan penggunaan software ChemSketch dengan urutan materi sesuai dengan materi dalam $e$-modul pelatihan yang telah disiapkan. Pada sesi pelatihan penggunaan ChemSketch dipandu oleh Esti Mulatsari, M.Sc, seluruh tim dosen dan mahasiswa berperan sebagai instruktur yang membantu menjawab pertanyaan-pertanyaan dari peserta saat berlangsungnya praktik. Pada kegiatan pelatihan ini setiap siswa menggunakan komputernya masing-masing dan bagi peserta yang tidak memiliki laptop tetap bisa mengikuti kegiatan dengan memperhatikan setiap tahapan kegiatan. Peserta berlatih menginstall software yang akan digunakan yaitu ChemSketch kemudian membuat struktur senyawa kimia dari struktur sederhana ke struktur kompleks dan seterusnya sesuai dengan urutan dalam materi pelatihan. Diakhir kegiatan pelatihan peserta diberikan soal yang harus dikerjakan menggunakan software secara mandiri. Gambar berupa struktur senyawa kimia yang telah dibuat dengan ChemSketch disalin (di-copy) dan kemudian di tempel (di-paste) pada slide powerpoint maupun dalam MS Word kemudian dikirimkan ke WAG peserta untuk proses penilaian. Kegiatan ini dilakukan untuk meningkatkan ketrampilan siswa dalam proses penyajian materi presentasi yang memuat materi-materi notasi atau symbol- 
simbol struktur kimia dan persamaan reaksi maupun ketika nanti menyusun artikel ilmiah dalam format Ms Word, selain itu hasil integrasi ini akan dijadikan acuan/tolok ukur kepahaman siswa dalam menerima materi pelatihan.

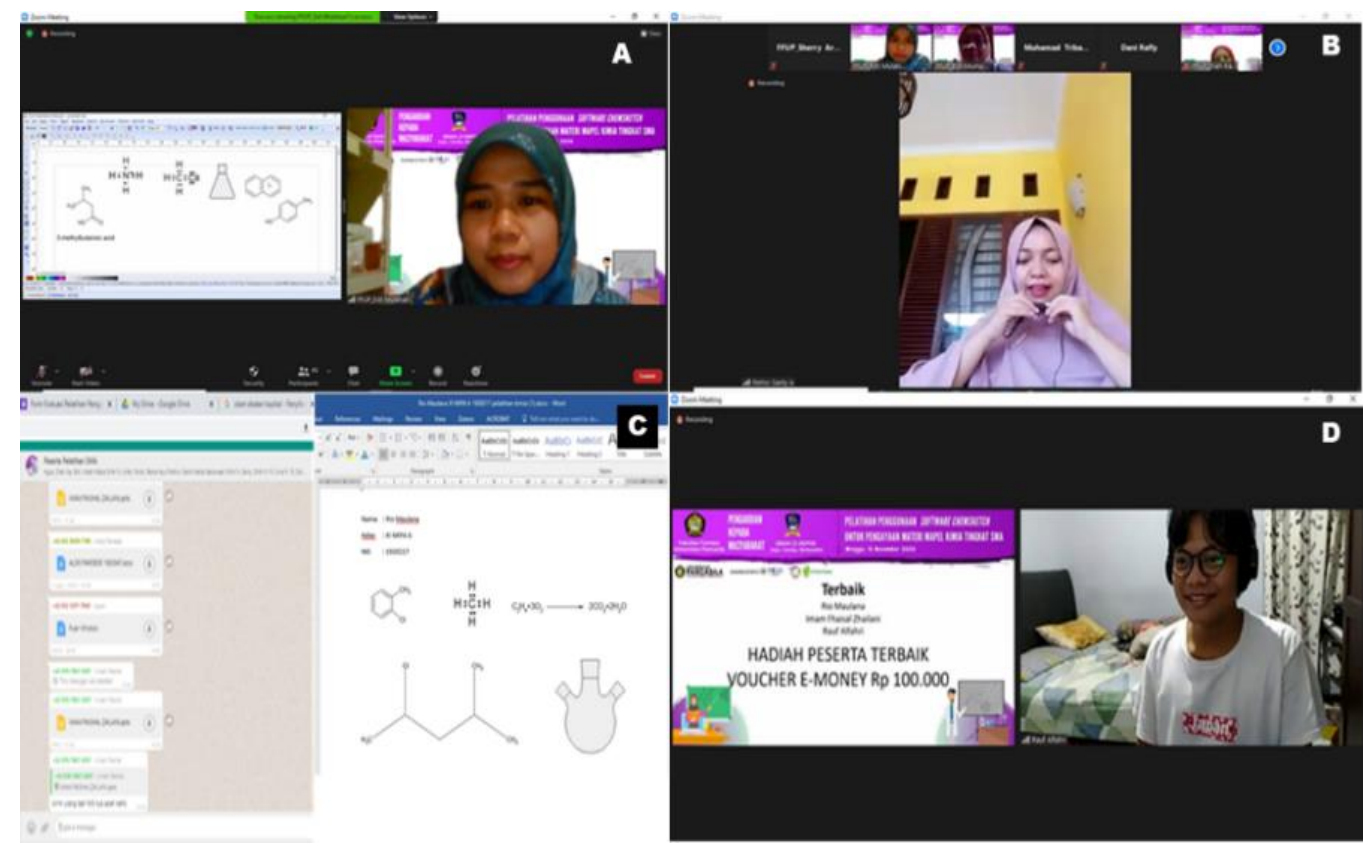

Gambar 3. Dokumentasi Pelaksanaan Kegiatan A) Salah satu instruktur menyampaikan materi, B) Sambutan Wakil Kepala Sekolah C) Hasil Latihan siswa, D) Penyampaian Pesan Kesan oleh Siswa

\subsection{Tahap Evaluasi Kegiatan}

Proses evaluasi dilakukan di akhir kegiatan dengan menilai penugasan yang telah dikerjakan oleh siswa, dimana penugasan tersebut disampaikan melalui wag peserta selain itu juga dilakukan evaluasi kegiatan secara kesluruhan dengan mengisi form evaluasi kegiatan. Beberapa aspek yang dinilai ditunjukkan dalam Tabel 3.

Tabel 3. Hasil Olah Kuisioner Evaluasi Kegiatan

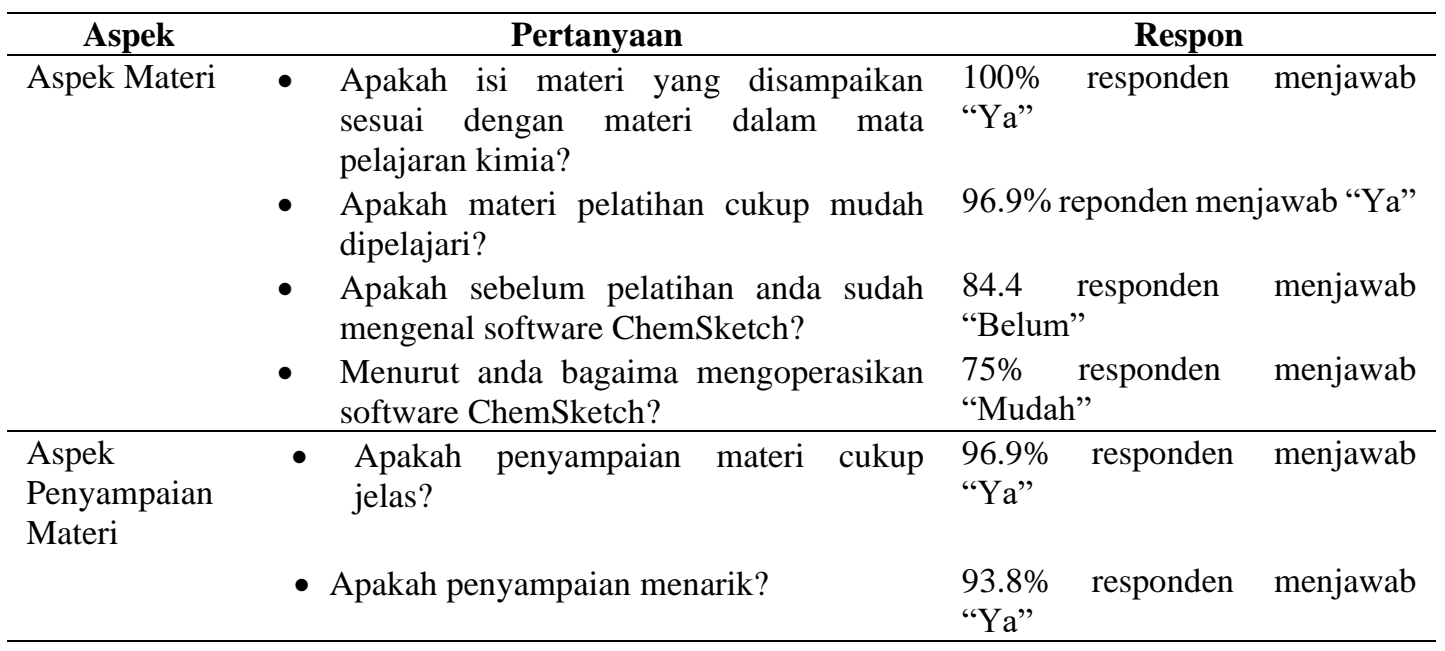


Dari kuisioner evaluasi kegiatan dapat disimpulkan bahwasannya, materi kegiatan merupakan hal baru bagi para peserta, penyampaian cukup menarik, mudah dipahami dan menambah wawasan bagi para peserta.

Kegiatan PKM ini telah dirilis melalui media

- Koran Radar Depok edisi 16 November 2020, dengan akses link https://www.radardepok.com/2020/11/ff-up-gandeng-sman-13-depokgelar-pk

- Koran Depok New edisi 16 November 2020 dengan akses link https://www.depoknews.id/program-kemitraan-masyarakat-oleh-timdosen-fakultas-farmasi-universitas-pancasila-pelatihan-onlinepengenalan-komputasi-untuk-siswa-sma-n-13-depok/

- Rekaman video kegiatan telah diupload pada youtube channel FFUP dengan link https://www.youtube.com/watch?v=2TsDorT3eP8\&t=5841s dan https://www.youtube.com/watch?v=8wDJ9DtdtRU\&t=27s

\section{SIMPULAN}

Mata pelajaran kimia memiliki berbagai macam simbol yang kadangkala sulit dipahami oleh siswa karena aspek-aspek simbolis ini terkesan rumit bagi sebagian besar siswa. Di SMA Negeri 13 Depok penyajian simbol ini dilakukan dalam bentuk 2D yang dituangkan pada selembar kertas. Hal ini membuat siswa jenuh dan sulit untuk memahami materi pembelajaran. Dengan berkembangnya teknologi, maka penyajian simbol dapat dilakukan dengan memanfaatkan komputer yang dapat menyajikan simbol secara 3D. Hal ini tentu akan sangat membantu siswa dalam memahami materi pelajaran. Namun demikian guru dan siswa di SMA Negeri 13 Depok belum memiliki pemahaman yang cukup dalam pemanfaatan teknologi komputer. Oleh karenanya pelatihan penggunaan software ChemSketch kepada para SMA Negeri 13 Depok menjadi hal yang sangat penting untuk meningkatkan skill para siswa. Software ChemSketch merupakan software yang mudah digunakan. Pelatihan software ChemSketch memberi banyak manfaat kepada siswa dan guru dalam hal mengayakan materi mata pelajaran kimia SMA Negeri 13 Depok, sekaligus mampu mengatasi permasalahan yang didentifikasi sebelumnya.

\section{UCAPAN TERIMA KASIH}

Ucapan terima kasih penulis sampaikan kepada LPPM Universitas Pancasila, atas dana pelaksanaan kegiatan ini melalui Program Hibah in House Pengabdian Kepada Masyarakat Universitas Pancasila.

\section{DAFTAR PUSTAKA}

Abraham, M., Varghese. V, \& Tang H. (2010). "Using Molekular Representation to aid Student understanding of stereomical concepts". Journal of Chemical Education. 87 (12): 1425-1429. 
acdlabs.com (2020). https://www.acdlabs.com/resources/freeware/chemsketch/

Arsyad, A. (2015). Media Pembelajaran. Jakarta: PT Raja Grafindo Persada

Asyhar, R. (2012). Kreatif Mengembangkan Media Pembelajaran. Jakarta: Gaung Persada (GP) Press.

Afnidar, Latif A., dkk. (2014). Materi Kurikuler Kimia SMP dan SMA. Universitas Terbuka. Tangerang Selatan. ISBN 9789790115026.

Direktorat Pembinaan SMA, Kemdikbud, (2017). Profil SMA: SMA Dari Masa ke Masa. Direktorat Pembinaan SMA, Direktorat Jenderal Pendidikan Dasar dan Menengah, Kementerian Pendidikan dan Kebudayaan. Jakarta Selatan.

Handayany, G.N., (2020). Manajemen Farmasi: Interaksi Pengobatan dalam Kasus Infeksi. Alaudin University Press, Gowa. ISBN: 978-602-328-294-4.

https://www.acdlabs.com/products/draw_nom/draw/chemsketch/

https://id.wikipedia.org/wiki/Komputasi

Muchtaridi (2018). Teknik Komputasi Hasilkan Obat Baru Secara Singkat, Murah, dan Strategis diakses melalui https://www.unpad.ac.id/2018/02/prof-muchtariditeknik-komputasi-hasilkan-obat-baru-secara-singkat-murah-dan-strategis/

Putri P. (2014). Modul Guru Pembelajar: Paket Keahlian Kimia Kesehatan Sekolah Menengah Kejuruan (SMK). Kelompok Kompetensi Reaksi Kimia. Direktorat Jenderal Guru dan Tenaga Kependidikan, Kementrian Pendidikan dan Kebudayaan

Sadiman, AS. (2014). Media Pendidikan: Pengertian, Pengembangan dan Pemanfaatannya. Jakarta: PT Raja Grafindo Persada

Suhendra, A., (2015). Komputasi Modern di Bidang Kesehatan. diakses melalui https://www.slideshare.net/aziz_suhendra/komputasi-

moderndibidangkesehatan 